The incomes of the colleges of agriculture and mechanic ants in $193^{-14}$, excluding the grants for experiment stations, amounted to $7,000,000 l$., made up as shown in Table 12 .

12.--Incomes of Agricultural and Technical Colleges,

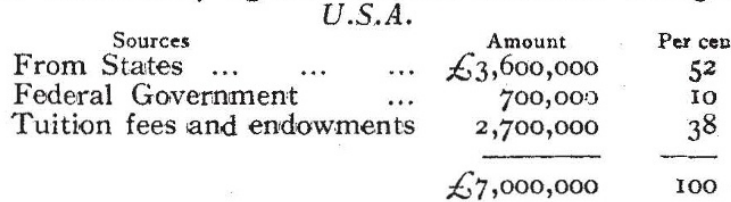

The total income of these technical colleges is thus nearly ten times that of the whole of the universities and colleges in England and Wales in receipt of Exchequer grants; and 60 per cent. is derived from State or Federal grants in comparison with 40 per cent. from Parliament and local authorities combined in the case of universities and colleges of England. It may be added that the normal State expenditure per annum on higher agricultural education in England and Wales is about $20,000 \mathrm{l}$., and $35,000 \mathrm{l}$. for agricultural research, or not much more than a single State in America receives for similar purposes.

The incomes of twenty-one German universities in 1913-14, not including the technical high schools, amounted to nearly $1,800,000 l$. ; and of this the State provided $1,500,000 l$, or more than 80 per cent. of the total. The universities with incomes approaching 100,000 l. or more are shown in Table 13.

\begin{tabular}{|c|c|c|c|c|}
\hline $\begin{array}{l}\text { University } \\
\text { Berlin ... }\end{array}$ & $\ldots$ & \begin{tabular}{c} 
Income \\
\hdashline 246,000
\end{tabular} & $\begin{array}{l}\text { State grants } \\
\$ 205,000\end{array}$ & $\begin{array}{c}\text { Per cen } \\
8 \mathrm{I}\end{array}$ \\
\hline Leipzig & $\ldots$ & $23 r, 000$ & 190,000 & 82 \\
\hline Breslau & $\ldots$ & II 2,000 & 82,000 & 73 \\
\hline Halle ... & . . & III,, 000 & 74,000 & 67 \\
\hline Bonn ... & $\ldots$ & 100,000 & 75,000 & 75 \\
\hline Kiel . ... & $\ldots$ & 99,000 & 65,000 & 66 \\
\hline Göttingen & $\ldots$ & 94,000 & 50,000 & 53 \\
\hline Königsberg & $\ldots$ & 92,000 & 72,000 & 80 \\
\hline
\end{tabular}

Some of the points brought out by the foregoing tables may be stated as follows :-

(I) In proportion to population, the United States has more than twice as many students of university standard as are in England; Scotland has more than three times as many; and Germany nearly three times as many.

(2) There are only 5000 full-time students of science and technology in the United Kingdom in comparison with nearly 17,000 in Germany and 34,000 in the United States.

(3) The total income of universities in the United States amounts to about $20,000,000 l$, and that of Ger. many to nearly $1,800,000$. The total income of al? the universities of the United Kingdom is about 2,00o,oool.

(4) Eighty per cent. of the total income of German universities is derived from State grants, in comparison with 34 per cent. contributed in Parliamentary grants to the modern universities of England and Wales.

(5) Thirty per cent. of the income of universities in the United States is derived from invested funds and donations, in comparison with ${ }^{5} 5$ per cent. in the modern universities of England and 6 per cent. in those of Wales.

(6) The tuition fees at universities of the United Kingdom form a much higher percentage of the total income than they do in the United States and Germany.

(7) Nine universities in the United States have individual incomes exceeding the total amount granted annually by Parliament to universities and institutions of like standard in the United Kingdom.

$$
\text { NO. } 2546 \text {, VOL. IOI] }
$$

(8) Five States of the United States give grants to their universities exceeding the amount of the Parliamentary grants to universities and colleges of England and Wiales.

(9) Private benefactions to universities and colleges in the United States amount to more than $5,000,000 l$. annually; in the United Kingdom they do not average one-twentieth that sum.

(I0) The colleges of agriculture and mechanic arts in the United States have a total income of $7,000,000 l$. or ten times that of the whole of the modern universities of England and Wales.

(II) The University of Berlin receives annually from State funds a grant nearly equal to the total annual Parliamentary grants to the universities and colleges of England and Wales.

It will be evident from these facts that in the domain of higher education the United Kingdom compares very unfavourably with the United States and Germany. No doubt one reason for this is that in America and Germany there has been a greater demand for highly trained men than in the British Isles, where posts for such men have been few, salaries low, and prospects poor. Conditions are, however, improving; and the industrial research associations being formed in connection with the Department of Scientific and Industrial Research, as well as associations established on the lines suggested by the Whitley Report, need for their successful operation the employment of men capable of undertaking research. The conditions of industrial development and the competition of other countries make it essential to secure an adequate supply of trained workers of this type.

Increased grants to universities and technical institutions are needed to enable the tuition fees to be reduced and to ensure that the staffs are paid salaries commensurate with the high qualifications demanded. The present aid given by Parliament is in no way adequate to modern needs, and compares very unfavourably with what is available in the United States and Germany. The grand total of all Parliamentary grants to universities and technical colleges of university rank in the United Kingdom is about 50o,oool., whereas the Federal and State grants in the United States amount to $7,000,000 l$, and in Germany to nearly $2,000,000 l$. The provision made by Parliament for higher education is thus obviously not that which should be expected of a State which intends to maintain its position among leading Powers.

R. A. Gregory.

\section{SCIENTIFIC ORGANISATIONS OF THE ALLIED NATIONS.}

$A \mathrm{~T}$ the invitation of the Royal Society, a conference $A$ between representatives of the Allied nations will be held in London on October 9 to discuss the future conduct of scientific organisations. It is expected that representatives from the academies of Paris, Rome, Tokyo, and Washington, as well as nominees of the Governments of Belgium, Portugal, and Serbia, will attend. A memorandum proposed by a committee of the Royal Society points out that international scientific organisations and conventions may be divided into four groups, according to their objects and methods of procedure. A first group consists of those important agreements which fix the standards of measurements, and are essential not only in purely scientific investigations, but also in the development of many industries. A second group contains associations definitely formed for the investigation of scientific problems in which co-ordination of observation is essential. A third group, which hitherto has not been large in numbers, but presents some special features, embodies the efforts to organise undertakings that might be carried out in one locality, 
but is more economically dealt with by a division of work. The most prominent example of this type is the arrangement made between eighteen observatories, to form a photographic chart of the heavens. The organisation dealing with the "International Catalogue of . Scientific Literature" may also be included in this group. In the fourth group is placed the large number. of congresses called together by workers in some one department of science, and mainly intended to foster friendly personal relationships between those who pursue similar aims in different countries. There is, finally, in a group by itself, the International Association of Academies, which aims at co-ordinating the activities of international undertakings, and organises work for which special permanent bodies do not exist and are not required. The council of the Royal Society will submit the following questions as subjects for discussion at the forthcoming conference:-(x) Is it desirable for the Allied nations to establish organisations for scientific co-operation among themselves? (2) If this be agreed upon, what should be the particular forms of organisation to be aimed at in geodesy, seismology, meteorology, etc.? . (3) Should particular academies be asked to submit proposals on those undertakings in which they have taken the leading part, such as: (a) The Académie des Sciences on the Commission Métrique and the Bureau International des Poids et Mesures; (b) The Royal Society on the International Catalogue of Scientific Literature? (4) What representations should be addressed to the Governments with regard to those organisations which have hitherto received their support? The conference at present is intended to deal only with scientific subjects. but similar questions no doubt also arise on the literary side.

\section{UNIVERSITY AND EDUCATIONAL INTELLIGENCE.}

WE learn from the Times that Prof. J. J. Findlay, professor of education in the University of Manchester, has accepted the invitation of the Y.M.C.A. Universities' Committee to become its director of education in Salonika, where it is hoped that an extensive system of classes and lectures will be developed during the autumn and winter. Prof. Findlay will leave for Salonika in September. To the work on the lines of communication in France which Sir Henry Hadow has undertaken for the committee will now be added similar service among the British troops in Italy.

The governors of the Royal Technical College, Glasgow, have appointed Dr. C. H. Desch to the chair of metallurgy in the college, rendered vacant by the resignation of Prof. A. Campion. Dr. Desch received his scientific training at the Finsbury Technical College, at Würzburg University, and at University College, London, under the late Sir William Ramsay. After eight years' practical experience as chemist in a chemical works, he was for five years research assistant to the professor of metallurgy in King's College, London; for the last ten years he has been Graham Young lecturer in metallurgical chemistry in Glasgow University.

THE Education Act received the Royal Assent on August 8, and is now, therefore, on the Statute-book. The following is a summary of the main changes in the provision of public education in England and Wales as given in the Times of August $9:-$ (I) No exemptions from attendance at school shall be granted to any child between the ages of five and fourteen. (2) Local authorities may increase the age of compulsion by by-law to fifteen. (3) Compulsory day continuation schools shall be established for all young persons, unless they are being otherwise educated, up to the age of sixteen, and after seven years from the appointed day up to the age of eighteen. (4) The minimum number of hours of attendance at continuation schools shall be 280 , and after seven years 320 . (5) No child under twelve shall be employed. (6) No child between twelve and fourteen shall be employed for more than two hours on any Sunday, or on any school day before the close of school hours, or on any day before $6 \mathrm{a} . \mathrm{m}$. or after 8 p.m. Exceptions may be made by bylaw, provided that no child may be employed for more than one hour before school, and if so employed, for more than one hour in the afternoon. $(\tau)$ Local authorities may make provision for the supply or maintenance of holiday or school camps, centres for physical training, school baths, swimming baths, and other facilities for social and physical training. (8) Provision is made for the medical inspection and treatment of pupils in secondary and continuation schools. (9) I Local authorities may establish nursery schools for children between the ages of two and five. (ro) Special schools are to be established for physically defective children. (I I) Fees in public elementary schools are abolished.

Representatives of the various Government Departments at Washington have recently held a number of conferences to consider, in response to the numerous requests of school officials, what American schools should do to render the utmost service of which they are capable during the war emergency. "The conclusions and recommendations resulting from these conferences are now published in the form of a leaflet for distribution to American teachers by the Washington Bureau of Education. So far as elementary schools are concerned, the representatives decided that there appears to be nothing in the present or prospective war emergency to justify curtailment in any respect of the sessions of these schools, or of the education of boys and girls under fourteen years of age, and nothing which should serve as an excuse for interference with the progressive development of the school system. It is suggested, however, that school activities with an educational value might be introduced, designed to connect the schools with the ideals of service and selfsacrifice actuating the American people. In the case of secondary schools it is suggested that much valuable service could be rendered by selecting and training boys to assist in meeting the need for agricultural labour. It would be helpful in industrial communities if, for secondary-school pupils above fourteen, definite courses could be introduced looking towards a co-operative half-time plan of school attendance and employment throughout the year. Boys and girls should be urged. American teachers are being told, to remain in school to the completion of the high-school course, and in increasing numbers to enter upon college and university courses, especially in technical and scientific lines, to meet the great need for trained men and women.

\section{SOCIETIES AND ACADEMIES.}

\section{EDINBURGH,}

Royal Society; July 8.-Dr. J. Horne, president, in the chair.-Dr. R. Kidston and Prof. W. F. Lang: Old Red Sandstone plants, showing structure, from the Rhynie chert bed, Aberdeensl.ire. Part ii. Additional notes on Rhynia Groynne-Vaughani, Kidst. and Lang; Rhynia major, n.sp.; and Hornea Lignieri, n.gen. et $\mathrm{sp}$. In this paper the species of Rhynia, which were included under one name in a former account, are distincuished as $R$. GroynneVaughani and $R$. major. The latter plant is iarger in all its parts, and lacks the adventitious branching found in $R$. Groynne-Vaughani; but its morphology 